\title{
IISTURBANCES OF SENSATION OCCASIONED BY EXPERIMENTAL ARREST OF BLOOD FLOW
}

\author{
ALFRED AUERSPERG * \\ ORLANDO AIDAR ** \\ EROS A. ERHART **
}

PART I - ISCHAEMIC PHASE

Lewis and his school ${ }^{22,23}$ as wel! as Gasser and associates ${ }^{16,17}$ have attempted to correlate disturbances of specific sensory categories clinically observed in experimental ischaemia of a limb to the fall and loss of excitability undergone in succession by the different diameter groups of nerve fibers submitted to ischaemia in laboratory experiments. For this correlation they compared the time of ischaemia required for the disappearance of each of the types of sensation with the duration of ischaemia necessary for the loss of excitability of each of the nerve fiber groups. Weddell and associates ${ }^{30,33}$ have directed their interest particularly toward the paresthesias which occur during and after stoppage of blood flow. In addition to the question as to which nerve fibers and receptors could be involved in the phenomenon they busied themselves with the manner of initiation and origin of the pathologic irritability which should underlie the paresthesias. The conclusions of these three outstanding investigators and their associates are in agreement, and they have interpreted the data of their experiments according to the methodically sound principles of classic physiology of sensation.

The neurologist can recognize in auto-experiments with ischaemia of a limb the dysesthesias and paresthesias which he encounters so often in the complaints of his patients due not only to involvement of peripheral nerves but also to the most variable focal disturbances of the sensory sphere. This frequency of similar disturbances in widely different affections of the nervous system awakens doubt as to their specificity. It is more probable that also in ischaemic experiments come central factor shares in determining the total type of predilection

Trabalho realizado no Depattantento de Arratomia da Fac. Mcá. da Univ. de Sāo Paul Prof. R. Locchi).

* Da Universidade de Vienna.

* Assistentes do Departamento de Anatomia da Fac. M!ed. da Univ. de São Paulc.

Nota da Redação - Êste trabalho é publicado em inglês nara facilidade de divulgação. Tratando de assunto que tem sido estudado, quase que exclusivamente, nos países anglo-saxóes, a publicação em portuzuês, mesmo com um "summary" pormenorizado, não teria as mesmas vantagens. Assim, a redação da revista solicitou dos autores a versão inglèsa do trabalho total, fazendo acompanhá-lo de extenso sumário em português, no qual figuram algumas expressões inglêsas intraduzíveis. 
of such sensory disturbances. In this paper we shall be concerned with the aspect of our results that refers to the existence of such a central factor in the production of sensory disturbances under ischaemic conditions.

The method used in the key experiments is the one outlined by Lewis and Pochin 23, in which blockage of circulation is performed by putting the cuff of a sphygmomanometer on the upper arm and bringing the pressure rapidly $(2-3$ scconds) up to $200 \mathrm{~mm} / \mathrm{Hg}$ while the limb is elevated. Thereafter the limb is put in the most comfortable position for the subject. That pressure was higher tha' the svstolic pressure of the subjects. All experiments were made on the present vriters and many were repeated on nine other persons.

For matter of convenience the sensory disturbances occasioned by sschaemia can be considered in the following successive phases: (1) Paresthetic, (2) Hyposthetic-dysesthetic, (3) Anesthetic, and (4) after release of compression, another Paresthetic phase. However, as stated ahove, only some aspects of these disturbances will be considered here.

(1) Paresthetic Phase - As soon as compression is made there often starts in the hand a very slight feeling of successive waves of cold and warmth. Between the first and second minutes of compression (sometimes a little earlier), and starting most often in the fingertips, slight "tingling" paresthesias appear which last for 4-5 minutes. After 8-12 minutes of compression the patient has a feeling of "velvety numbness" which usually starts also in the fingertips. This represents the heginning of the second or hyposthetic-dysesthetic phase.

Several experiments were made in order to ascertain whether or not the sensory disturbances of this first phase are entirely dependent on peripheral changes. Results seem to indicate participation of ceniral factors, both for the tingling sensation and the thermic paresthesias. As will be explained below, we attribute to these disturbances "interoceptive" nature and significance.

When compression of both upper arms is made synchronously, the paresthesias appear in both hands with strikingly symmetrical timing and character: A warm or a cold wave seems to run synchronously through both hands, and if tingling starts, let us say, in the tip of the third finger, it will be bilateral, and will seem to increase and decrease in intensity synchronously on both sides. The same happens when finally the other fingers are also involved; after 10 minutes the feeling of velvety numbness sets in, also symmetrically.

This symmetry of the sensory disturbances could be attributed to the idcntical experimental conditions in both limbs, but the following asymmetrical circumstances gave rise to the same synchronism and symmetrical projection of the paresthesias in the laands, which seems to indicate interference of a central phe- 
nomenon: (a) The limbs were submitted to different temperatures before compression, but no effect was noted on the symmetry of the sensory disturbances; (b) neither was the latter altered by differences in pressure on both sides, as for instance $180 \mathrm{~mm} / \mathrm{Hg}$ on the right and $220 \mathrm{~mm} / \mathrm{Hg}$ on the left. But then Weddell noticed no influence of temperatures or of pressures higher than $160 \mathrm{~mm} / \mathrm{Hg}$ on the sensory fields in experimental ischaemia; (c) symmetry and synchronism of paresthesias were never affected either when compression on one side followed compression on the other after intervals of up to 20 seconds. However, when compression is applied in succession to the arms with longer intervals (40 seconds or so) the paresthetic phase may start earlier on the side first compressed, bit here again symmetry and synchronism may set in, unless the time interval is too long.

Tingling seems to coincide in timing with the peak of what physiological recordings indicate as a temporary hyper-excitability of ischaemic nerve fibers, a correspondence we shall discuss below along with the fact that the degree of hyper-excitability is such as to occasion spontaneous discharges in some fibers.

These paresthesias show some interesting features which seem to support our point of view. For instance, when the paresthetic field is slightly pressed with the point of a pencil tingling ceases in the surrounding area, so that the point of pressure is then distinctly perceived, as clearly as in the corresponding region of the normal hand. One of us (A.A.) had had his attention drawn by his co-worker Brücke ${ }^{2}$ to a similar abolishment of tingling in cases of nerve lesions.

Such critical sensory changes as follow immediately a certain stimulus are of the greatest physiological interest since the psychologic and physiologic changes observed separately, but under the same circumstances, are conceivably concomitant and superimposable.

Kugelberg ${ }^{20}$ also noticed that an adequate stimulus causes tingling to cease around the stimulated point, and he recorded spontaneous discharges of low frequency in the ischaemic nerve which coincide in time of appearance with tingling. When these fibers undergoing spontaneous activity are submitted to stimulation of higher frequencies their spontaneous impulses of low frequency are eliminated, apparently because they fall in the refractory phases caused by the more frequent ones. The abnormal impulses are thus replaced by the orderly ones induced by external excitation. As we see it, the same fibers, under the same metabolic conditions, are thus responsible for the two different perceptions: for the paresthesias when the fibers are undergoing disorderly temporal activity, and also for the normal sensation induced by adequate stimulation, namely, the definite, localized feeling of punctiform pressure over the indifferent background of the surrounding paresthesias-free area. These are, therefore, two types of reaction to afferent impulses carried by the same fibers, one representing the abnormal state of the limb, and another specifically related to the encounter with 
an external stimulus. In the following pages we shall refer to the first type as being of an "interoceptive" nature and the second, "exteroceptive".

(2) Hyposthetic-dysesthetic Phase - This starts with the appearance of a feeling of "velvety numbness" in the fingertips, from where it spreads proximally as ink in a blotter. At the same time the threshold to touch increases, pain and temperature sensations undergo gradual changes and finally the third or anesthetic phase is reached.

The concomitant fading of exteroceptive functions (hyposthesias) and appearance of interoceptive presentation (velvety numbness) of the hyposthetic limb is a common occurence in almost every disorganization of the sensory sphere, and might conceivably be a compensatory mechanism. Through this mechanism the patient is able to correlate the disturbed exteroceptive impression of his exploring hand to the abnormal interoceptive dysesthesias and paresthesias felt in that hand, so as to avoid or minimize objective errors. During this phase of the experiment there is a gradual passage from a normal disposition for encountering external stimuli to a state of profound numbness of the ischaemic hand, and in the process the subject develops an almost uncontrollable tendency to avoid contacts with that hand.

As stated before, both exteroceptive and interoceptive types of changes may be a function of the same morphologic substratum. Whereas we would think of them as being equivalent consequences of the sensory disorganization, occasioned by a temporal disruption in the coordination of the afferent impulses, the current opinion ascribes them to an increasing functional deficiency of the receptor-conductor system, as can be inferred from the following quotation from Sinclair ${ }^{30}$ : "Some 10 minutes from the start of compression, if the affected hand is lightly stroked by the hand of the experimenter, a very slight but unmistakable alteration in the quality of the sensation perceived becomes evident. This change is perhaps best expressed by saying that the subject - who normally feels hymself possessed of a uniformly sensitive "smooth" receptive surface for touch in the skin - now becomes aware that this surface is no longer completely smooth, but appears to le composed of a fine meshwork of sensory spots. The onset of this change is not easily detected without practice, but the subjective 'mesh' of skin receptors becomes progressively coarser, and by about the 15 th minute it is easily perceived as the velvety numbness' previously described by Weddell and Sinclair. The progressive coarsening of the mesh proceeds further until eventually complete anaestesia supervenes, at a time varying with the individual." 
Description of sensory experiences is of course difficult, especially when of an interoceptive nature. "Velvety numbness" and "waxy feling" are the common designations for this sensation. We would point out, however, that under this state the subject does not perceive a smooth object as rough, as might be expected from the coarsening of the subjective mesh of skin receptors (Sinclair), but on the contrary it is the rough that seens to be smooth, and also humid. "Waxy" and "velvety" seem to have in common an element of plasticity of the surface. To this is attriouted the general blurring of the sensation of contact with the source of stinulus during the phase of central transformation of the type of reaction from exteroceptive to interoceptive. Then, the suject ceases to feel the actunl contact of the point of a needle, and becomes aware only of pain within his finger, deep, penetrating as an incandescent point or ray. The sensations of cold and warmth at the contact of an object undergo also gradual loss of objective significance and become penetrating; instead of indicating the thermal characteristics of the object they now participate in the interoceptive concept of the altered state of the hand.

In other words, we attribute to abnormal afferent impulses (elicitcd by external stimulation as in velvety numbness, or spontaneous) the subject's interoceptive concept of his abnormal hand. Through this change the external stimuli cease to indicate the object itself and become referred instead to the abnormal hand. This interoceptive representation of the paresthetic limb is comparable to interoceptive pain in disease; like the latter sensation, velvety numbness also causes the subject to protect the affected part from external stimulations, and to keep it quiet. Like painfulness in a sick part, increasing numbness influences the well-being of the individum; as Weddell puts it, "velvety numbness is sickening".

Turning now more especially to exteroceptive function, we believe that its normality also depends on the-normal coordination of afferent impulses as inferred from Kugelberg's findings. This is of course much more vague than the current theories of neurophysiology, according to which quality, intensity and localization of sensations depend on specific anatomico-physiological fundaments. Intensity, for instance, is held as in parallel correlation with the number of the stimulated fibers having the same specific function and localizing significance, and the frequency of their impulses. This would imply that any reduction in number of fibers or frequency of their impulses would determine a proportional fall in intensity of a given sensation, and would so explain hyposthesias. We feel, however, that there must be a central factor in this connection. We would admit that the central mechanisms are 
able to make up for some deficiencies, and to perform satisfactorily also when only a part of the impulses arrive in an orderly manner. This would be another, broader, compensatory mechanism than the one already discussed with reference to the double representation. The latter obviates an error that would arise from partial or total disorganization of afferent impulses by attributing the changes to the receptor and not the object, by switching from exteroceptive to interoceptive sphere. In the other case compensation for avoiding objective crror would take place within the exteroceptive sphere itself, in spite of disorganization (physiologically detectable) of the afferent impulses. The first type of compensation was discussed with the hyposthetic-dysesthetic phase of ischaemic disturbances of sensation; the second will be considered in the following pages.

Physiological data on ischaemic nerves indicate that the greater their activity (and therefore their metabolic requirements) is, the earlier do the changes in excitability appear. ${ }^{9}$ After a transitory rise, the excitability drops and disappears, and does so faster in the active than in the quiescent state. Now, if the lack of response of the ischaemic receptor field were an immediate consequence of the loss of excitability, as is the current belief, then the receptor fielci would behave as in "Schwellenlabilität" described by Weizsäcker and Stein, ${ }^{34}$ a condition found often in funicular myelosis for instance, and consisting of loss of excitability occasioned by a gradual rise of threshold on repeated stimulation. Therefore, one would expect anesthesia to develop earlier in a continuously stimulated ischaemic area than in the vicinity. But this was not the case. We stimulated a fingertip by repeated light friction (twice a second) from the start of blood arrest until development of anesthesia in the hand, and observed that hyposthesia and anesthesia appeared synchronously in the stimulated and non-stimulated fingers, both supplied by the same nerve.

Of the various receptors, the muscle spindles were the ones best studied in ischaemia. According to Matthews, ${ }^{24}$ after some variations in excitability there is an abrupt final stage of high frequency discharges by the receptors, and then complete inexcitability. This final stage was found to appear earlier when the muscle was kept in activity.

The following tests were planned to ascertain whether such abnormal changes in excitability and its carly loss interfere in the perceptive functions related to the afferent impulses discharged by those proprioceptors: I - The subject was ask $r$ d to estimate variable weights suspended by a string running over a wheel and attached to the distal phalanx of his finger; the weight was moved up and down by flexions and extensions of the finger while the hand rested on the table. II The subject had to estimate the weight (varying between 50 and $300 \mathrm{gm}$ ) of otherwise similar little bags that were put in his hand. III - The subject had to hit a target with those same little bags of different weights. IV - The 
subject was asked to keep pumping rhythmically on a rubber bulb so as to bring the column of mercury of a manometer always to the same level, with his eyes closed and until exhaustion.

All tests were made under normal and under ischaemic conditions of the arm; and the cuff was put around the upper arm as usual. Each type of test was run several times, also after having submitted the muscles to several degrees of exercise so as to reach several gradations of fatigue and painfulness. The brevity of the ischaemic tests did not allow for precise observation and measurement of the changes in function. As far as we could judge, however, there were no noticeable differences in performance and estimation under normal and ischaemic conditions of the arm.

Matthews observed that the spontaneous discharges occurring during ischaemia do not occasion locomotor or static reflexes; and he believes these impulses to be related to ischaemic muscle pain. Both statements support our belief that the irregular, incoordinated impulses are related to interoceptive representation.

With reference to the compensatory mechanism limited to the exteroceptive functions, we must be satisfied with the statement that the afferent impulses maintain their exteroceptive significance under ischaemic conditions, in spite of the changes they undergo and that can be shown physiologically. As stated before, we explain the correct interpretation of the stimulus under such conditions assuming that a part of the afferent impulses maintain their normal coordination. Though physiological data are lacking, psychological evidence of the so called "super-determination" of perceptive function is amply supported in all fields of sensory activity. Super-determination is well exemplified by the effect of light punctate pressure on a paresthetic field, namely the disappearance of tingling from the depressed funnel of skin, and the clear perception of the stimulating object. That this is not a mere suppression of the afferent impulses responsible for the paresthesia is well shown in an experiment by Frey and Strughold. ${ }^{15}$ They anesthetized an area of skin of about $2 \mathrm{~cm}$. in diameter by novocaine iontophoresis, and exercised pressure in its center. As long as the deformation in the skin was entirely included in the anesthetized area, the subject could not detect the stimulus; but he reported feeling of pressure in the center of that area as soon as the boundary was passed by the deformation. The same happens in cases of segmental anesthesias; as soon as the limit of the anesthetized area is passed by the deformation of skin, the patient localizes the point of pressure correctly, instead of referring it to the surrounding normal field. 
These examples demonstrate that the impulses arising from the surroundings of the stimulated point cause no representation of their origin; they serve to indicate the actual point of contact. The exteroceptive function, even in its simplest form, is therefore superdetermined and well protected.

The great advantage of ischaemic experiments is that the central mechanisms are left intact while the peripheral structures are submitted to well defined and localized disturbances. According to classical physiology the intact central nervous system records almost like an instrument the deficiencies (hyposthesias and anesthesia) and abnormal states of excitability (paresthesias) of the periphery. We feel that such strict parallelism does not exist, and that the central mechanisms have a capacity for compensation. Compensatory phenomena were observed by Euddenbrock and by Bethe (cited by Bethe and Kast ${ }^{8}$ ) in connection with motor functions, and we believe to have shown that such is also the case (and to a large measure) in the sensory sphere, that the central nervous system achieves it through a dual type of compensation, namely distinct interoceptive and exteroceptive evaluation of afferent impulses, and superdetermination of exteroceptive functions.

PART II - POST-ICHAEMIC PHASE

Weddell and Sinclair ${ }^{33}$ describe in detail the paresthesias appearing 40 to 50 seconds after release of a blockage of blood flow which had lasted about 15 minutes. We shall discuss here the paresthesias they call "pins and needles", for which there are several physiological interpretations. The main aspects to be discussed refer to the following well known facts:

I - Pins and needles (release pricking) start at the fingertips, where they are most intense, and spread proximally with diminishing intensity, but do not pass the limits of the hand. II - Ceteris paribus, intensity and spread of pins and needles are greater the higher the level of arrest of blood flow in the arm. In the standard experiment pressure of $200 \mathrm{~mm} / \mathrm{Hg}$ is applied to the middle part of the upper arm; when the cuff is put at the lower end of the forearm these paresthesias are weak and quite localized, even if the blockage be continued for 30 minutes. III - Two cuffs were applied, one at the arm and the other at the lower jar: of the forearm. Releasing only the upper blockage we observed pins and needles after the same latency and with the same intensity and distribution as in the standard experiment, as if the lower blockage were not there at all. IV - As is well known, tapping the fingers reinforces these parcsthesias at the points of contact and in the immediate vic nity; it also makes them appear earlier, or reappear just after they have ceased. Regular compression of the paresthetic finger has the same effect, only to a minor degree. 
The field of origin of the abnormal impulses responsible for these paresthesias was considered to be the ischaemic nerve by Lewis ${ }^{22,}{ }^{23}$, the ischaemic muscle by Bazett and McGlone, ${ }^{6}$ the pain receptors at the site the pins and needles are felt, Weddell and Sinclair. ${ }^{33}$ The last named authors have shown that the other two hypotheses are not sufficient to explain all the known facts concerning pins and needle:s.

Lewis takes as a starting point the fact that in an ischaemic limb hoth anesthesia and "release pricking" appear first at the fingertips. This similarity in localization of phenomena of opposite natures is considered by him as an indication of disturbance to the same morpholological substratum. Lewis showed that compression of the nerve itself leads to anesthesia in the same distal localization, and observed that after discontinuing the pressure on the nerve there appear paresthesias identical to "release pricking". He concluded, therefore, that both phenomena are related to the same fibers, the ones supplying the fingers, and formulates the hypothesis that vulnerability of nerve fibers under ischaemic conditions is directly proportional to the distance between their receptor field and the level of blockage. As a matter of fact Groat and König 18 have shown, in nerve fibers of asphyxic cats, rhanges in excitability which increase proximally.

Weddell and Sinclair confirmed Lewis' observations on the appearance of tingling and gradual anesthesia by exercising pressure on the region of the sulcus bicipitalis, so as to compress the nerve without interfering with the circulation, but they state further that the paresthesias which follow release of pressure do not show the characteristics of "pins and needles", but those of "buzzing", "pseudocramp" and "tingling". Sinclair points out, furthermore, that in this case anesthesia does not spread gradually as in ischaemic experiments, but shows some discontinuity from one nerve field to another. Also, the findings of Groat and König do not fit exactly Lewis' observations. They found a hyperbolic increase in the vulnerability of nerve fibers to asphyxia as one proceeds towards the roots while the gradient of vulnerability is quite reduced in the periphery. It should be pointed out, however, that Lewis' experiments were confined to the periphery. These were the objections to his interpretation.

Bazett and McGlone ascribe release pricking to a muscular field because this paresthesia is much weaker when blockage of circulation is at the lower end of the forearm. These authors believe that pins and needles are caused by chemical agents of metabolic origin, so that exclusion of the highly metabolic muscle masses from the ischaemic territory would account for the lower intensity of the paresthesias. In favor this belief they state further that warning the ischaemic limb exaggerates release pricking, while cooling has the effect of greatly di- 
minishing the paresthesias. Weddell and Sinclair disagree with this explanation, and point out that, in spite of being weak, pins, and needles still appear after blockage of circulation at the level of the wrist. And they could not find regular influence of warming and cooling on release pricking. Neither did we.

Weddell and Sinclair believe that pins and needles originate in the receptor field of the fingertips, as indicated by their localization, and this because: (1) the most distal parts of the extremities would be the most affected by an incomplete block of circulation; (2) the higher intensity of paresthesias at the fingertips would correspond to the greater density of sensory spots in these regions; (3) intensity of these paresthesias is quite a bit lower when blockage of blood flow is exercised below the level of the elbow, or at the wrist, as compared to those following compression in the upper arm. According to Weddell and Sinclair this is to be explained by (a) the better protection of the vessels at these lower levels, hindering a full arrest of circulation, as indicated by (b) the smaller reactive hyperhaemia after release of blockage, suggesting smaller accumulation of vasodilator substances, and therefore a lesser degree in arrest of circulation, as compared to what is obtained by compression at the upper arm; (4) in a case of amputation of the hand no pins and needles were felt in the phantom after release of compression on the upper arm. The absence of the receptor field would account for the lack of the paresthesias.

However, against these indirect evidences we would point out that: (1) according to Müller's ${ }^{28}$ revision of the literature the fingertips are not the most affected parts during incomplete arrest of circulation, and that because their vessels follow the direction of the main vessels of the limb; (2) Weddell and Sinclair admit that pins and needles are related to pain, in which case there would be a conflict with Strughold's ${ }^{32}$ observation that the density of pain spots is in inverse relation to that of touch, and the high density of touch spots in the fingertips is well known; (3a) Weddell states that the increase of pressure from $160 \mathrm{~mm}$ up to $300 \mathrm{~mm} / \mathrm{Hg}$ does not affect the sensory disturbances caused by ischaemia. So we wonder whether or not that would apply here too, and whether the increase of pressure up to $300 \mathrm{~mm} / \mathrm{Hg}$ in the forearm would not compensate for the better protection of the vessels in this segment; ( $3 \mathrm{~b})$ the difference in the degree of hypernaemia after release of blockage in the arm and in the forearm might not be indicative of accumulation of chemical substances. Stopford and Telford ${ }^{31}$ showed that vasoparalytic circulation is much greater when the vasomotor nerve fibers are interrupted at the level of the arm than after division at the region of the wrist; (4) the lack of 
release pricking in the phantom of the amputated hand is very interesting. But sensory experiences caused by peripheral stimulation (adequate to produce paresthesias in normal subjects) are not well known in cases of amputated limbs with or without phantoms, and may be subject to unpredictable changes. For instance, on faradic stimulation of the median nerve in cases of amputation of the hand the patients often will refer paresthesias to the fingertips (as normal suhjects do) provided they have phantoms. However, when phantoms disappear the patients start to report paresthesias at variable points of the stump, but then the paresthesias are much weaker than before. and sometimes they disappear altogether with the phantom.*

To these indirect objections against the hypothesis of Weddell and Sinclair on the origin of release pricking in the receptor field we might add others of a more direct nature, as for instance their own observation that no difference could be detected by oncometric measurements of the fingers after release of blockage of circulation at the wrist as compared to that at the upper arm; this seems fair indication against the belief that circulation in the finger is more affected by the higher blockage and our following tests seem to offer further evidence against their hypothesis :

I - One finger was tightly wrapped with a rubber band from the tip to its root before compression was exercised on the upper arm. After release of blockage, pins and needles appeared in that finger with almost the same intensity as in the others. II - One finger was anesthetized by encircling its root with novocaine before circulation was arrested at the upper arm. Again, after release of blockage, pins and needles were felt in that finger with practically the same intensity as in the others.*

The cutaneous receptor field (Weddell and Sinclair) and the muscle receptors (Bazett and McGlone) may have greater or lesser importance in the syndrome of release pricking, but we believe that the essential role is played by the nerve fibers themselves, as Lewis first pointed out.

Pins and needles occur frequently in focal diseases of the most variable localizations in the nervous system. They are a common experience in neurology, but rare in dermatology uniess the lesion affects the nerves along with the skin; when the lesion is limited to the receptor field, itching or pain may be felt rather than paresthesias.

The predilective localization of these paresthesias in the fingertips is a very interesting phenomenon, as is also the fact that anesthesia developing during ischaemia starts in the same site, as pointed out

* Merrington and Nathan 25 have just published similar results on the same subject.

** Erhart ${ }^{13}$ offers further profs in experiments on compression of nerves. 
by Lewis. Several other instances of this predilection can be mentioned, both under experimental circumstances and in disease. One example is the greater degree of hyposthesia distally in case of partial lesion of the median nerve. On the other hand, faradic stimulation of this nerve in any part of its course gives rise to paresthesias which are most intense at the fingertips. The same is true in cases of multiple sclerosis or other disseminated changes in the central nervous system; that is, the resultant paresthesias and hyposthesia are felt in most cases in the tips of the limbs. Well circumscribed lesions in the post central cortex usually result also in sensory disturbances at the tips of the limbs. As a matter of fact, the distal parts of the limbs have the largest cortical representations as evidenced by several methods 5 , $11,12,16$.

The coinciding predilection of opposite phenomena like paresthesias and hypo- or anesthesia for the same localization deserves more attention, as this would seem paradoxical from the viewpoint of classical physiology. Indeed, the appearance of paresthesias at fingertips after stimulation of as different parts of the nervous system as a peripheral nerve and the cortex would be another of the many evidences of the multiple and wide representation of these parts. And from the parallelistic point of view this would indicate that these parts of the limbs have the richest nerve supply and the most elahorate nervous mechanism, which would also allow for ample compensations in cases of partial disturbances of conduction and perception. This, of course, does not hold, as ischaemic hyposthesia and anesthesia also start at the fingertips, as we have seen. In a broad sense, we night say that the exteroceptive function of the sensory field seems to be the more vulnerable the greater is its tendency for introceptive, i. e. paresthetic, representation. What would seem a paradox from the classical point of view fits well the hypothesis we have advanced in preceding paragraphs, i. e., afferent impulses in the same system of nerve fibers will give rise to exteroceptive or interoceptive representation of the segment according to whether they do or do not maintain respectively a definite coordination. So the empirical rule that hyposthesia (as a symptom of change in the exteroceptive function) and paresthesia (as interoceptive representation) start in the same region (fingertips) seems to agree with our theoretical deductions, based on Kugelberg's physiological analysis of tingling.

Our line of reasoning can be expanded so as to explain some clinical and experimental (in ischaemia) observations, and in so doing we deviate still further from the classical concept. In discussing interoceptive representation we have mentioned so far only definite sensations as paresthesias, pain, itching, etc. But in hyposthetic and 
anesthetic types of interoceptive representation the sensation sometimes is not so definite. It may be but a peculiar feeling of numbness or waxy feeling, as representation changes from exteroceptive to interoceptive type; then, the subject experiences dysesthesias when stimulated, but no spontaneous paresthesias. We would suggest also that the representation of a numb region is dependent not only on lack of afferent impulses but also on some kind of incoordination of impulses, which does not give rise to pain or paresthesias "sensu stricto". If so, this would be a peripheral phenomenon comparable to syndromes of central inhibition, caused by a localized disturbance in a highly differentiated system, as for instance in diaschisis ${ }^{26}$. The following preliminary experiment seems to support that hypothesis:

A nervus digitalis volaris proprius in the ischaemic hand was stimulated with A.C. current of 60 cycles; the necessary intensity to arouse strong paresthesias and pain was near the maximum that could be tolerated, and stimulation was only discontinued when paresthesias disappeared. After about two minutes of stimulation the subject reports marked decrease of paresthesias and pain in the field of distribution of the nerve; another minute later these almost disappear and numbness is felt instead. Mechanical stimulation revealed then great increase in the threshold for touch and pain, in fact almost anesthesia. At first we interpreted these findings as being due to ischaemic changes of excitability, but a few seconds after electric stimulation had been discontinued numbness disappeared and those thresholds decreased. New electric stimulation reproduced the effects of first, comparable to the eifects of electric stimulation in the neighboring fingers. Practically identical phenomena were observed on the normal (non-ischaemic) hand. So it was not just a matter of ischaemic changes of excitability of iatigue (60 cycles is in the range of nonfatigability, at least for A ribers), but conceivably some sort of a central to the incoordinated nerve impulses. In similar experiments Heinbecker observed disappearance of pain on faradic stimulation. And Wolff reports that in order to maintain on faradic stimulation of a tooth stimulation had to be intermittent. More physiological evidence is needed to demonstrate the mechanism of these phenomena, and whether it is a matter of change of excitability in the periphery or, as we think, a central adaptation and reaction to incoordinated afferent impulses.

Another aspect in the study of the significance of post-ischaemic paresthesias is the influence that the various stimuli may have on them. When contact is avoided, thermic and painful stimulation have no effect on release pricking. Touch and pressure on the other hand are quite effective, and up to a certain point there is even a certain direct proportion between degree of pressure and intensity of the pins and 
needles; in that sense, however, tapping is by far the most effective stimulation. Tapping the fingers will even cause pins and needles to appear before or after these paresthesias are spontaneously felt. This accentuation is probably due to participation of the pressure receptors, when stimulated by an abrupt contact, which indicates encounter with the object. Muscle and tendon receptors might participate also; this seems quite logical if we think of their role in the control of the movements by which the animal reacts to the environment. And usually the representation of the movement is referred to the distal end of the limb, as such or as an instrument of that movement 4,5 . This is also true when the limb is "lengthened" or shortened. The wonderful precision of a hammer in the hand of a sculptor and of the loop of a lasso thrown by a cowboy are examples of the importance of muscle receptors for the transference of that representation. The same occurs in cases of amputation, as evidenced by those wlo have a clear phantom limb in rest; as they draw the figure 8 in the air with the stump, the phantom disappears, indicating transference of representations to the end of the stump. We have already mentioned the localization of paresthesias in the stump, an evidence of the influence that this pattern of action has on interoceptive representation. In short, the hability to localize contact stimuli correctly presumes objective representation of the part of the limb effecting the contact. This representation is also a scheme to determine somatotopically the point of contact. The role of the muscle receptors in this representation makes understandable their participation in the accentuation of paresthesias at the moment of contact (tapping).

Kugelberg found in the peripheral nerves, chiefly in the post-ischaemic phase, a development of excitatory centers from which volleys of highly frequent impulses arise spontaneously, at regular intervals. When stimulated by impulses of other origins, they discharge impulses of high frequency during a long time. Kugelberg attributes to this fact the accentuation of post-ischaemic paresthesias by tactile stimulation. But this does not explain all our findings. For instance, with the exception of tapping, stimulation of the muscle receptors does not accentuate release pricking. On the basis of Matthews' findings that muscle receptors undergo high excitability after release of blood arrest and that pressure on the muscle is an effective stimulation to these receptors, one would expect to obtain enhancement of release pricking by pressing the muscles of the same territory. Furthermore, when a finger is anesthetized with novocaine before blockage of circulation on that side, on release of blood arrest pins and needles appear spontaneously in that finger as in all the others; but then, tapping that finger fails to accentuate the paresthesias, in spite of the fact that the 
muscle receptors were not in the anesthetized field. It seems to us that the accentuation of release pricking by tapping is a specific phenomenon related to the encounter of the fingers with an object, for which touch and muscle receptors work in coordination. Another fact that supports our belief is that when release pricking is decreasing, simple pressure causes the paresthesias to disappear around the point of pressure, similarly to what happens with tingling; but tapping continues to accentuate the paresthesias. Pressing the fingers firmly against a table causes the pins and needles to disappear, without even an initial accentuation. This might be due to one of two possibilities: Either it is due to a central interference aroused by the intentional determination of the subject not to tap but only to press his fingers, or a retrograde elimination of previous impulses by the ones initiated by the pressure, in the same way a word acquires its significance only after its last sound is heard. In their "facilitation retroactive" Pierron and Segal ${ }^{29}$ exemplify this phenomenon down to problems of elementary thresholds.

Summarizing our beliefs, we attribute to post-ischaemic paresthesias the quality and localizing nature of a sensitive reaction of predilective type of non-specific and ambiguous physiological significance. With reference to the post-ischaemic paresthesias we agree with Lewis, that they arise in the afferent nerve fibers; impulses initiated at receptors would only have a role in modifying the paresthesias. The interpretation of our findings was based on Kugelberg's findings. In trying to identify the afferent fibers responsible for post-ischaemic paresthesias we determined the adequate stimuli necessary to modify them, and consequently the implied receptors, and fibers themselves. We assumed, therefore, that the modifying effect of a stimulus indicates the participation of the fibers in the production of the paresthesias. It has been shown that muscle, pressure and touch receptors can influence the paresthesias, and it seems to us that the abnormal state of excilability of a given afferent system, as demonstrated by Kugelberg by parallelistic analysis, does not fully explain the specific changeability of post-ischaemic paresthesias. The stimulation of muscle receptors accentuates the paresthesias only when the impulses thus aroused are associated with others streamming from tangoreceptors, i.e., when a purposeful perceptive function is at play, to indicate an intended or casual encounter of the limb with an object.

\section{S U M M A R Y}

Disturbances of sensation in the hand were studied during and after experimental arrest of circulation to the arm. Blockage of circulation was performed as outlined by Lewis and Pochin, by putting 
the cuff of a sphygmomanometer on the upper arm and bringing the pressure rapidly up to $200 \mathrm{~mm} / \mathrm{Hg}$. The experiments listed below were intended to demonstrate the variability of a central reaction brought about by fairly definite disturbances of the ischaemic periphery. All experiments were made on the present writers and repeated on nine other subjects, none of whom had systolic pressure reaching 150 $\mathrm{mm} / \mathrm{Hg}$.

I - Blockage of circulation in both arms led to symmetrical phenomena in both hands (thermal paresthesias, tingling and hyposthesia), both under symmetrical experimental circumstances, and under the following variations: So long as the cuff pressure on both arms was above the systolic blood pressure, differences as great as $300 \mathrm{~mm} / \mathrm{Hg}$ in one cuff and $150 \mathrm{~mm}$ in the other did not alter the symmetry of the effects. Neither was symmetry and synchronism of paresthesias affected when compression on one side preceded equal compression on the other up to 20 seconds.

II - When a punctate pressure is applied to the paresthetic field the paresthesias disappear around that point and the latter is clearly brought out from the indifferent background produced in the area of depressed skin. On the basis of Kugelberg's findings, it seems that this occurs because the impulses caused by pressure have a higher frequency and substitute the spontaneous abnormal discharges of the ischaemic nerve fibers.

III - Repeated mechanical stimulation of a fingertip during the experiment failed to show any influence on sensory (touch) thresholds, in contrast, therefore, to what would be expected on the basis of the physiologic experiments which show rapid fatigue of ischaemic structures.

IV - In contrast to what might be expected from the intense changes undergone by receptors in the muscies during ischaemia, as observed by Matthews, weight discrimination and the capability of hitting targets with objects of different weights were not significantly altered, even during the painful phase of fatigue.

$\mathrm{V}$ - A nervus digitalis volaris proprius was stimulated with A.C. current of 60 cycles at a just tolerable intensity. After three minutes of stimulation the initial paresthesias and pain had almost disappeared, and were followed by numbness and increased sensory thresholds in the field of distribution of that nerve. A few seconds after stimulation was interrupted, sensation was again normal in that field. Comparable phenomena were observed under normal conditions, in the absence of ischaemia.

VI - Novocaine block of a finger in the ischaemic side did not influence "pins and needles", which appear after arrest of circulation is released. Therefore, the field of origin of the "pins and needles" 
does not seem to be the receptor field (Weddell and Sinclair) but more probably the nerve fibers themselves (Lewis, Kugelberg).

VII - As is well known, "pins and needles" are accentuated by tapping the fingers and, much less, by pressing them. Thermic and painful stimulation have no effect on these paresthesias. Tapping would probably stimulate muscle and touch receptors. On the basis of our observations and Kugelberg's physiological analysis, we are inclined to consider the nerve fibers of these receptors as the field of origin of these paresthesias.

VIII - No accentuation of "pins and needles" was found by (a) tapping an anesthetized finger, nor (b) pressing the muscles; but (c) tapping the fingers does reinforce these paresthesias, also during the phase when simple pressure has the opposite effect of extinguishing them. So, it seems that accentuation is related to specific nerve fibers, but it is only brought about when a special function is at play. 'Therefore, enhancement of those paresthesias is limited to the correlated function of proprioceptors and touch receptors when indicating the moment of encountering an object.

The following conclusions drawn from these observations seem to show the variability of central sensory reactions to experimental disturbances of the ischaemic periphery.

Hyposthesias and paresthesias observed in an ischaemic limb are specially intense at the fingertips and behave, therefore, according to the type of predilection of most focal disturbances in the sensory sphere of the nervous system. This shows that the structures that are best supplied with afferent nerve fibers have no greater capacity to compensate for limited disturbances but are, on the contrary, the most vulnerable substrata of function. On the basis of Kugelberg's analysis of spontaneous impulses in ischaemic nerve fibers it seems to us that the coordinated afferent inpulses resulting from a stimulus are related to exteroceptive functions, whereas the spurious irregular impulses give rise to the interoceptive representation of the abnormal status of the ischaemic hand (II). The symetry and synchronism of paresthesias and numbness (referred to in I) indicate that the interoceptive representation of the abnormal hand, as well as the disturbances of sensation to external stimuli, do not follow exactly the ischaemic disturbances in the periphery; on the contrary, they seem to develop in an autonomous order of predilective type. This independency of the reaction from the causative disturbance make numbness and the dysesthetic changes comparable to interoceptive pain and tenderness of visceral origin. Besides the change in the type of reaction, our observations show also the following compensations and modifications of the exteroceptive functions, in correlation with a partial incoordination 
of the afferent impulses: lack of lability of thresholds as demonstrated by continous stimulation of the sense of touch (III) and stimulation of the muscle receptors (IV); development of numbness and hyposthesia on continous faradic stimulation of a nervus digitalis proprius (V).

To identify the functional substratum affected under ischaemic conditions, the effect of certain stinuli on the paresthesias was observed, and these were correlated to Kugelberg's physiologic findings (II and VII). Going beyond Kugelberg's conclusions our findings seem to indicate that not only specific fibers as such, but only specific fibers under specific functional conditions can modify the paresthesias.

The type of reaction is the factor that transforms an anatomic substratum to a functional one. In itself, this statement, is not contrary to the classical concept. In classical studies of reflexes, for instance, estimation of quantitative relation between stimulus and effect depends on a previous "adjustment" producing a constant functional substratum (pattern). However in ischaemic experiments, as ours have shown, one is not dealing with a constant type of reaction, but with one of a changeable nature; function and effects of stimulation influenced by central factors should always be taken into consideration in the light of that variability, so that deductions of parallelistic nature may be avoided.

\section{S U M A R I O}

Nossas pesquisas se referem às perturbaçōes da sensibilidade da mão, durante e após o bloqueio da circulação sangüínea no braço. Para efetuarmos o bloqueio, procedemos do mesmo modo que Lewis e Pochin, colocando o manguito de um tonômetro no tèrço superior do braço e produzindo, ràpidamente, uma pressão de $200 \mathrm{~mm} \mathrm{Hg}$. As experiências abaixo refericlas visaram demonstrar a variabilidade da reação central, em face das perturbações mais ou menos definidas da periferia isquemiada. Fizemos as experiências em nós mesmos, comprovando-as em mais nove pessoas:

1 - Bloqueando a circulação de ambos os braços, foi verificacla simetria de fenômenos (parestesias de tipo térmico, formigamento $\mathrm{e}$ hipoestesia), mesmo quando o bloqueio da circulação não foi simultâneo (um efetuado 20 segundos depois do outro), nem de mesma intensidade (150 e $300 \mathrm{~mm} \mathrm{Hg}$.)

2 - Efetuando uma pressão circunscrita no campo parestésico, verificamos o desaparecimento das parestesias em tôrno do ponto comprimido; explicamos êste fenômeno, seguindo Kugelberg, admitindo que as excitações desencadeadas pela pressão, suplantam as excitações espontâneas patológicas das fibras isquemiadas, quando as primeiras ultrapassam as segundas em freqüência. 
3 - Estimulando, por processos mecânicos repetidos, a ponta do dedo durante a experiência isquemiante, não foi observada influência alguma sôbre os limiares da sensibilidade; observamos, portanto, o contrário do que seria de esperar segundo as experiências fisiológicas do esgotamento prođuzido nas organizaçôes excitadas sob condições isquemiantes.

4 - A avaliação dos pesos e o ato de atingir o mesmo alvo com pesos variados, mesmo na fase dolorosa de esgotanento, não evidenciou erros consideráveis; isto indicaria uma faculdade compensadora central, pois as pesquisas de Matthews demonstraram alterações fundamentais dos receptores musculares sob condições isquemiantes.

5 - Faradizando de modo contínuo o nervo próprio de um dedo com potencial ainda suportável e na freqüência de 60 por segundo, verificamos que, depois de 3 minutos, as parestesias e dôres iniciadas desapareciam quase totalmente, dando lugar a uma sensação de adormecimento, com elevação dos limiares da sensibilidade no campo de inervação do nervo faradizado; cessada a estimulação, a sensibilidade normal se restabeleceu en poucos segundos. Parece que êsse fenômeno não é muito influenciado pelas condições isquemiantes, pois manifestações pràticamente idênticas foram observadas ao executarmos a mesma experiência em dedos não isquemiados.

6 - A anestesia de um dedo da mão isquemiada não influiı nas parestesias denominadas "pins and needles", que aparecem depois de cessado o bloqueio. O campo de origem dos "pins and needles" parece não residir, portanto, no campo receptor (Wedclell) mas sim nas fibras nervosas aferentes (Lewis e Kugelberg).

7 - Como é sabiclo, os "pins and needles" são muito reforçados pelo "tapping" e, muito menos, pela simples pressão; estimulações dolorosas e térmicas não têm influência sôbre as parestesias. Pelo "tapping" seriam estimulados os receptores dos músculos e do tacto; aplicando a análise fisiológica de Kugelberg, deveremos considerar as fibras aferentes dêsses receptores, como o campo de origem das excitações anormais, produzindo os "pins and needles". No entanto: ( $a$ ) não há, no dedo anestesiado, refôrço dos "pins and needles" pelo "tapping"; $(b)$ a pressão sôbre os músculos também não produz refôrço dos "pins and needles"; $(c)$ o "tapping" produz um refôrço também na fase en que a simples pressão produz o fenômeno contrário da extinção. Estas últimas experiências mostram, portanto, que o refôrço se correlaciona a fibras determinadas, mas, exclusivamente ao executar uma função especial. Assim, o refôrço das parestesias se limita à função correlacionada dos receptores musculares e receptores do tacto, ao indicar o momento do encontro com o objeto. 
As experiências acima referidas nos levam às seguintes conclusões que visam mostrar a variabilidade das reações centrais sensitivas, en، face de perturbações experimentais produzidas na periferia isquemiada.

Hipoestesias e parestesias do membro isquemiado se localizam de preferência nas pontas dos dedos e se comportam, assim, de acôrdo com o tipo de predilç̧ão da maioria das perturbações focais da esfera sensitiva do sistema nervoso. Evidencia-se, dêsse modo, que não são os sistemas mais ricos em fibras aferentes os que têm maior capacidade para compensar defeitos limitados, e que, pelo contrário, êles se comportam como os substratos funcionais mais vulneráveis. Aplicando a análise das excitações espontâneas nas fibras isquemiadas (Kugelberg), admitimos que os impulsns aferentes de coordenação normal exercem uma função exteroceptiva, enquanto que os impulsos incoordenados desencadeiam uma representação interoceptiva do estado anormal da mão (Exp. 2). A simetria e a sincronização das parestesias e do adormecimento, demonstráveis sob condições experimentais (Exp. 1), indicam que, tanto a representação interoceptiva do estado anormal da mão, como as alterações da sensibilidade exteroceptiva, não acompanham de modo exato as perturbações isquêmicas da periferia, mas se desenvolvem segundo uma ordem autônoma de tipo eletivo. Nessa independência de reação com caráter caprichoso, o adormecimento e as disestesias se comportam da mesma forma que a dor interoceptiva e a hipersensibilidade à dor (tenderness) provocadas por estimulação visceral.

Acompanhando a variação do tipo de reação, observamos, em nossas experiências, as seguintes compensações ou alterações da função exteroceptiva frente à incoordenação parcial dos impulsos aferentes: como compensações. notamos a falta da labilidade dos limiares, apesar da estimulação contínua do tacto (Exp. 3) e dos receptores musculares (Exp. 4) : como alterações, observamos o aparecimento de adormecimento e hipoestesia por estimulação farádica contínua de um nervo digital próprio (Exp. 5).

A fim de identificar o substrato funcional alterado na experiência isquemiante, determinamos quais os impulsos adequados para modificar as parestesias em questão. Esses fenômenos subjetivos foram correlacionados aos achados de Kugelberg (Exp. 2 e 7); ultrapassando as conclusões de Kugelberg, nossas experiências indicam que as excitações de determinadas fibras modificam as parestesias, sòmente quando exercendo função especial.

De modo geral, é o tipo de reação que imprime caráter funcional a um determinado substrato anatômico. Esse ponto de vista não é, em si mesmo, contrário ao conceito clássico, pois também as idéias clássicas mostram que é necessário estabelecer em primeiro lugar - por exemplo, pela decerebração - um ajustamento central (adjustment) que 
representa um substrato funcional constante (reflex pattern), possibilitando, assim, a pesquisa quantitativa da relação entre o estímulo e o efeito. Nossos achados demonstram, no entanto, que, nas experiências isquemiantes, o modo de reação do sistema nervoso e variável; nessas condições, não é possível tirar dedıções imediatas quanto ao estado de excitação da periferia isquemiada, correlacionando de modo paralelístico, respectivamente, o estado de hipoanestesia com substrato deficitário e o estado parestesia-disestesia com substrato irritativo. Não havendo alteração do sistema nervoso central, o paciente compensa, com seus mecanismos psicológicos de integração sensitiva, as alterações determinadas na periferia. De outro lado, as manifestações parestésicas apresentam o caráter caprichoso das reações interoceptivas em geral, não permitindo o estabelecimento de uma relação unívoca entre o estímulo e o efeito.

\section{BIBIIOGRAFIA}

1. Adrian, E. $\Gamma$. and Zotterman, Y. - The impulses produced by sensory nerve endings. J. Physiol., 61: 151-171, 1926.

2. Auersperg. A. - Das Schema das getasteten Gegenstandes. (To be published by Enke Verlag. Stuttgart),

3. Aluarsperg, A - Das Schema des eigenen Körpers und seiner Glieder. (To be published by Enke Verlag, Stuttgart).

4. Amersnerg A - Dal Riancos Formesetz der schwunghaft durchgeführten Bewegung. Deutsche Ztschr f. Narvanh. 156(4/6):21?-2??. 1944.

5. Rard. $P$ - Condies in the enrtical representation of smmatic sensibility. The Harvey Lertims 1037-193 Williams and Wilkins Co., Baltimore. 1938.

6. Rasett H. $r$. and Mr Glone. R. A. - A rheminal fantent in the sareation of tinaling sensations during and after release of stasis. Pror. Sre. Fxp. Biol. Now York. 29: 87-88 1931.

7. Bazett, H. C. - Investigations of sensation in man. Assoc, Res. Nerv. a. Ment. Dis., $15: 83-97,1935$.

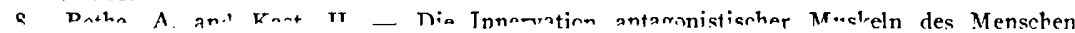
nach Versuchen an Sauerbrurh-Onerierten. Klin. Wchnschr.. 1: 581, 1922.

9. Bronk, D. W. - The influanme of circtlation on the activity of nerve cell. Assoc. Res Norv. a. Ment. Dis., 18: 299-316. 1938.

10. Bronk. D. W and Stella. F - Tha restonso to ctrady nressures of single end rmans in the isolated carotid sinus. Am. J. Physiol,, 110:708-714. 1935.

11. Cushing. $H_{\text {: }}$. A note $\mathrm{nm}$ the faradic stimulation of the post-central gyrus in con. scious patients. Brain 32: 44.1909

12. Dusser Du Barenne - Exnerimental researches on sensory localisation in the cere?ra! cortex of the monkey. Proc. Res. Soc., 96:272, 1914.

13. Erhart, E. A. - Nerve compression as an essential factor causing ischaemic and post-ischaemic paraesthesiae. To be published by Arquivos de Neuro-Pe..... - .

14 Foerstar. O. - Die Leitungsbahnen des Schmerzgefühls. Urban u. Schwarzenberg, Berlin.Wien, 1927.

15. Frey. M. von and Strughold, H. - Ist der Drucksinn einheitlich oder zwiespältig? Ztschr. f. Piol., 86: $181-186$. 1927.

Nerv. a, Ment. Dis., 15: 35-39, 1935.

16. Gasser, S. H. -- Conduction in the nerves in reaction to fiber types. Assoc. Res.

17. Gasser, S. H., Clarck, D. and Hughes, J. - Afferent function in the group of nerve fibers of slowest conducting velocity. Am. I. Psysiol. 114: 69, 1935.

18. Groat, R. A. and Koenio. H. - Centrifugal deterioration of asphyxiated peripheral nerves. J. Neurophysiol., 9: 275-284, 1946. bd. 3, 1 Kriess, J. von - Allgemeine Sinnesplysiologie. In Nagels Handbuch der Physiologie, 
20. Kugelberg, E. - Injury activity and trigger zones in human nerves. Brain, 69: \$10-325, 1946.

21. Lotze, H. - Allgemeine .Physiologie des körperliche Lebens. Leipzig 1851.

22. Lewis, Th. Pickering, G. W. and Rothschild, P. - Centrifetal paralysis arising out of arrested blood flow of the limb. Heart, 16:1-32,1931.

23. I.ewis, Th. and Pochin, E. D. - Effects of asphyxia and pressure on sensory nerves of man. Clin. Sc., 3: 141-155, 1938.

24. Matthews, B. H. C. - Nerve endings in mammalian muscle. J. Physiol., 71: 1-53, 1933.

25. Merrington, W. R. and Nathan, P. W. - Post-ischaemic paraesthesiae. J. Neurol., Neurosurg. a. Psychiatry, 12:1-18, 1949.

26. Monakow, C. von and Mourgue, R. - Introduction biologique à l'étude de la neurologic et de la psycopathologie. Alcan Éd., Paris, 1928.

27. Müller, J. - Handbuch der Physiologie des Menschen. I.eipzig, 1833-1840.

28. Müller, O. - Die feinsten Blutgefässe des Menschen. Ferdinand Enke Verlag, Siuttgart, 1937.

29. Piérron, H. and Segal, J. - - Sur un phenomène de facilitation retroactive dans l'exct. tation életrique de branches nerveuses cutanées (sensibilité tactile). J. Neurophysiol., 2: 178. $191,1939$.

30. Sinclair, D. C. - Observations on sensory paralysis produced by compression of a kuman limb. J. Neurophysiol., $11(2): 75-92,1948$.

31. Stopford, J. S. B. and Telford, E. D. - The distribution of vaso-constrictor fibers in the limbs. J. Anat, 67: 417, 1932-1933.

32. Strughold, H. - Die Dichte der Schmerzpunkte auf der menschliche Haut. Ztschr. f. Biol., $80: 367,1923$.

33. Weddeil, G. and Sinclair, D. C. - "Pins and needles". Observations on some of the sensations aroused in a limb by the application of pressure. J. Neuiol., Neurosurg. a. Psychiat,, 10: 26.46, 1947.

34. Weizsäcker, V. von and Stein, H. - Zur Pathologie der Sensibilität. Ergebn. d. Physiol., 27: 657-708, 1928.

35. Weizsäcker, V. von - Der Gestaltkreis. Georg Thiente, 3. Auflag, 1947.

Departamento de Anatomia da Fac. Med. da Univ. de São Paulo - Brasil. 